\title{
ANDRZEJ ROZWADOWSKI, OBRAZYZ PRZESZŁOŚCI. HERMENEUTYKA SZTUKI NASKALNEJ, POZNAŃ 2009
}

\author{
ANDRZEJ ROZWADOWSKI, IMAGES FROM THE PAST: \\ HERMENEUTICS OF ROCK ART, POZNAŃ 2009
}

ABSTRACT. The review of A. Rozwadowski's „Images from the Past: Hermeneutics of the Rock Art” underlines its innovative approach to the complexity of the problem presented in this study.

Wizerunki postaci ludzkich i zwierzęcych oraz symbole wyryte i namalowane w jaskiniach i na skałach dolin Europy, Azji Środkowej, Afryki, Australii czy Ameryki Północnej już od schyłku XIX w. przykuwały uwagę badaczy, wielokrotnie stanowiąc tematykę mniej lub bardziej popularyzatorskich opracowań. Najnowszą pozycją podejmującą ten temat jest praca Obrazy z przeszłości. Hermeneutyka sztuki naskalnej autorstwa Andrzeja Rozwadowskiego, jednego z niewielu polskich specjalistów w dziedzinie sztuki naskalnej. Od ponad piętnastu lat prowadzi on czynne badania dotyczące petroglifów, szczególnie na słabo dotąd rozpoznanych naukowo terenach Azji Środkowej. Niniejsze opracowanie stanowi rozwinięcie idei zawartych przez autora w poprzedniej monografii Indoirańczycy - sztuka i mitologia. Petroglify Azji Środkowej ${ }^{1}$. Prezentuje on bieżący stan badań w tej dziedzinie, a także nowatorskie podejście interpretacyjne, uwzględniające najnowsze koncepcje metodologiczne, które wpisują się w nurt ,,archeologii kulturoznawczej”2.

Omawiana monografia składa się z pięciu części. Pierwsza z nich została poświęcona definicji pojęcia sztuki naskalnej w kontekście współczesnego rozumienia słowa „sztuka”. Znalazł się w niej ponadto opis przykładów sztuki naskalnej z obszaru całego świata, prezentujący ją w skali chronologicznej, a także charakterystyka metod, wykorzystywanych przy jej datowaniu. Krytyczny przegląd teorii wyjaśniających znaczenie sztuki naskalnej, od koncepcji ewolucjonistycznych do podejścia strukturalnego, zawarty został w drugiej części pracy. Trzecia część monografii rozwija ideę tekstualności sztuki naskalnej. Autor podaje w niej zalety i wady postrzegania rytów jako tekstu kultury, a także podejmuje próbę przełamania impasu, wiążącego się z podejściem strukturalistycznym, wyjście, z którego upatruje w kontekstualizacji sztuki naskalnej. W części czwartej podejmuje on refleksję nad przestrzenią, w której umieszczone zostały ryty

\footnotetext{
${ }^{1}$ Rozwadowski 2003.

${ }^{2}$ Kowalski 1999.
} 
i malowidła (jaskinie, miejsca trudno dostępne, a także eksponowane powierzchnie skalne), oraz rozważa ich wpływ na kształtowanie krajobrazu kulturowego, odwołując się do dynamicznie rozwijającego się $\mathrm{w}$ ostatnich dekadach nurtu archeologii krajobrazu (landscape archaeology). Piąta część pracy, poruszająca zagadnienie szamanizmu i przeżyć transowych oraz ich znaczenie dla interpretacji sztuki naskalnej, jest bezpośrednim nawiązaniem do wspomnianej już poprzedniej monografii tegoż autora i rozwinięciem tez w niej postawionych.

Terminy „sztuka naskalna” i „ryty, malowidła naskalne” zdają się w sposób bezpośredni odnosić do pojęcia sztuki. Sztuka, jakkolwiek nie ma jednej, ogólnie przyjętej definicji, to w potocznym rozumieniu odnosi się najczęściej do wytworów ludzi obdarzonych talentem, ocenianych w kategoriach piękna, często w odseparowaniu od spełnianych przez nie funkcji utylitarnych ${ }^{3}$. W społecznościach plemiennych nie istnieje zaś kategoria sztuki w takim rozumieniu, nieodłączną cechą wszelkich wytworów tych społeczeństw jest ich funkcjonalność ${ }^{4}$. Jednym $z$ wielu na to dowodów może być przytaczana przez A. P. Kowalskiego próba rekonstrukcji porządku wartości dawnych Indoeuropejczyków, w których słowniku nie istniało specjalne słownictwo obsługujące sferę sztuki $^{5}$. Tak zwane społeczności pierwotne określają wizerunki naskalne zazwyczaj w kategoriach ,rysunek - znak". Sztuka naskalna jest zatem przez Autora rozumiana jako rodzaj tekstu, zapisany nie za pomocą alfabetu, ale graficznego systemu komunikacji. Zakłada on kilka możliwych poziomów odczytania - rozumienia takiego tekstu - poziom samego znaku, natury języka sztuki naskalnej i jego gramatyki oraz poziom podłoża, na którym tekst został „zapisany”, tj. poziom skały. Odczytanie - rozumienie języka sztuki naskalnej dokonuje się wedhug autora w drodze interpretacji, a co za tym idzie postuluje on aktywną rolę interpretatora jako istotnej determinanty procesu rozumienia.

Pierwsze refleksje nad sztuką naskalną pojawiły się wraz z jej odkryciem i dotyczyły paleolitycznych malowideł z jaskiń na obszarze Europy. Wpisywały się one w koncepcję sztuki dla sztuki, gdyż człowiekowi pierwotnemu odmawiano zdolności myślenia abstrakcyjnego, a zatem tworzone przez niego wizerunki nie mogły mieć znaczenia religijnego, metafizycznego czy informacyjnego. W wyjaśnianiu sztuki naskalnej szybko zwrócono się jednak ku analogiom etnograficznym, z których zaczerpnięto teorie magii łowieckiej i płodnościowej, jak również sugestię o totemicznym charakterze przedstawień naskalnych. Autor krytycznie odnosi się do mocy eksplanacyjnej analogii etnograficznych, jakkolwiek nie neguje zupełnie możliwości ich wykorzystania do interpretacji sztuki naskalnej, przy poczynieniu odpowiednich założeń metodologicznych, z których podstawowym wydaje się ich kontekstualizacja. Analogie etnograficzne miałyby w tym ujęciu stanowić zestaw możliwych konfiguracji znaczeń, mogących odnosić się do przedstawień naskalnych. Przykładowe wykorzystanie danych etnograficznych zostało

\footnotetext{
${ }^{3}$ Bugaj 2003.

${ }^{4}$ Kowalski 1999.

${ }^{5}$ Kowalski 2007.
} 
zaprezentowane przy interpretacji południowoafrykańskiej sztuki naskalnej. Sztuka ta, wykonywana w tradycji buszmeńskiej, charakteryzuje się stosunkowo niedawnym czasem powstania, co umożliwiło postawienie pytań o znaczenie jej twórcom. Autor podkreśla jednak konieczność stałego odwoływania się do samych przedstawień i konfrontowania ich z wiedzą etnograficzną, jak również wagę interpretacji obu kategorii danych.

Wraz z przełomem strukturalistycznym pojawiło się (obowiązujące zresztą do dziś) podejście do sztuki naskalnej jako rodzaju wypowiedzi, z założenia poddanej wewnętrznym regułom, generowanym przez pewien system językowy, oraz dążenie do ich rozpoznania, przy jednoczesnym odniesieniu do kontekstu danej wypowiedzi. Autor omawianej pracy zwraca jednak uwagę, że tekstualizacja sztuki naskalnej niejednokrotnie pociągała za sobą próby jej linearnego odczytywania, postrzeganie rytów tylko w sposób dwuwymiarowy. Autor krytycznie odnosi się też do wysuniętej przez strukturalistów tezy, że pojedynczy ryt skalny nie ma sam w sobie wartości znaczącej, a wynika ona dopiero $\mathrm{z}$ relacji, w jakich dane przedstawienie znajduje się względem innych rytów. Postuluje on uwzględnienie trzeciego wymiaru tejże sztuki, jakim jest skała i patrzenie na całość kompozycji, nie zaś na pojedyncze znaki i związki linearne pomiędzy nimi. Odczytywanie nie może bowiem ograniczać się tylko do prób rekonstrukcji „składni” naskalnego tekstu. Autor wielokrotnie podkreśla, że pierwszy człon nazwy „,sztuka naskalna" bardzo długo dominował w sposobach interpretacji, przysłaniając niejako znaczenie skalnego podłoża dla odczytania możliwych znaczeń tego zjawiska.

Kontekstualizacja analogii czerpanych z badań etnograficznych stała się dla autora punktem wyjściowym do nowego odczytania sztuki naskalnej poprzez pryzmat metafor łączących ją z innymi sferami działań kulturowych (autor wymienia tu mit i rytuał). Rozpatruje on metaforę nie tyle jako zjawisko czysto językowe, ile raczej kulturowe. Jak stwierdza P. Ricoeur: „można rozważać grę metaforyczną na różnych poziomach organizacji w zależności od tego, czy badamy metafory w poszczególnych zdaniach [...], czy też metafory typowe dla jakiejś społeczności językowej lub kultury, co można rozumieć tak szeroko, by ogarnąć wielkie obszary kulturowe [...]. Wreszcie, pewne metafory są tak radykalne, że zdają się ogarniać cały dyskurs ludzki”,

Czytanie poprzez pryzmat metafory daje możliwość różnych interpretacji, wobec zawieszenia $w$ jej ramach instancji weryfikacji i falsyfikacji logicznej; definiowanie poprzez metaforę nastawione jest na sferę nieokreśloności, przedmioty przez nią wyznaczane mogą pozostać wieloznaczne, domniemywane ${ }^{7}$. Współgra to z uwagami autora o dynamizmie semantycznym sztuki naskalnej, zawierającym się w możliwości jej reinterpretacji. Znaczenie nadawane jej w momencie stworzenia nie jest ani jedyne, ani ostateczne. Możliwości nowych odczytań pojawiają się wraz z różnymi tradycjami, w ramach których wizerunki mogły funkcjonować (np. sztuka Indian Pueblo i Nawahów, działania chrześcijańskich misjonarzy wobec południowoamerykańskiej sztuki

\footnotetext{
${ }^{6}$ Ricoeur 1989, s. 149.

${ }^{7}$ Stępnik 1988, s. 126-137.
} 
naskalnej czy muzułmańskich osadników w stosunku do azjatyckich wizerunków naskalnych), a także wraz z dystansem czasowym oddzielającym dane przedstawienia od ich późniejszych interpretatorów nawet w ramach jednej tradycji kulturowej.

Już w poprzedniej pracy poświęconej petroglifom Azji Środkowej A. Rozwadowski przyjął założenie, że u podstaw sztuki naskalnej leżą przeżycia transowe i wierzenia ich dotyczące ${ }^{8}$. Rozwijając w omawianej monografii wątek transowy, przywodzi przykłady południowoafrykańskich i północnoamerykańskich przedstawień naskalnych, które interpretowane są jako wizualizacja stanów zmienionej świadomości. Nie neguje jednak możliwości innych, pozatransowych, inspiracji dla tworzenia tego rodzaju sztuki - odnoszących się do rytuałów inicjacyjnych, różnych typów magii, w tym łowieckiej. Próba dotarcia do psychicznych i somatycznych doświadczeń szamanów oraz innych osób przeżywających stany transowe ukazała, że ryty naskalne mogą być traktowane jako wizualizacja tych stanów. Konfrontacja tych danych ze źródłami etnograficznymi, dotyczącymi wierzeń różnych plemion, przemawia za ich postrzeganiem jako rzeczy samych w sobie, bardziej odrębnych bytów niż przedstawień czy zapisu.

Jak już wspomniano, wykorzystywany w omawianej książce model czytania sztuki naskalnej poprzez metaforę nie poddaje się falsyfikacji logicznej. Zauważa to zresztą sam autor. W jego obronie przytacza on argument o własnej, wewnętrznej logice modelu, pociągającej za sobą stałe odniesienia do badanego zjawiska, ujmowanego przez pryzmat „kodu” kultury, która je wygenerowała. Wypada się zgodzić, że model ten otwiera nowe możliwości odczytania różnych kategorii źródeł, poprzez odnalezienie i wyjaśnienie związków zachodzących pomiędzy nimi, a innymi sferami działań kulturowych, w tym przypadku pomiędzy sztuką naskalną, a mitem i rytuałem. Jego wykorzystanie pozwoliło autorowi na zidentyfikowanie wielopoziomowości symboliki sztuki naskalnej.

Monografia A. Rozwadowskiego jest cenną poznawczo naukową publikacją poruszającą tematykę stosunkowo mało znaną w polskiej archeologii. Dzięki głębszej refleksji metodologicznej i wykorzystaniu szerokiej podstawy źródłowej zaprezentował on nowe podejście do problemu interpretacji sztuki naskalnej. Przyjmując założenie o relacji pomiędzy rytami a praktykami szamańskimi i konsekwentnie trzymając się go aż do końca. Autor zmienił charakter odczytania tego zjawiska i uwypuklił jego metaforyczność. Na koniec warto zauważyć, że praca napisana jest bardzo przystępnym językiem, zrozumiałym również dla osób spoza kręgu badaczy pradziejów, a szerokie odniesienia do innych nauk - filozofii, językoznawstwa, antropologii czy botaniki pomagają ogarnąć złożoność problemu w niej poruszonego.

BIBLIOGRAFIA

Bugaj E.

2003 Problemy interpretacji zjawisk sztuki w archeologii w kontekście nieoczywistości sztuki, (w:) Estetyka w archeologii, red. B. Gediga, A. P. Kowalski, Gdańsk, s. 11-20.

\footnotetext{
${ }^{8}$ Rozwadowski 2003.
} 


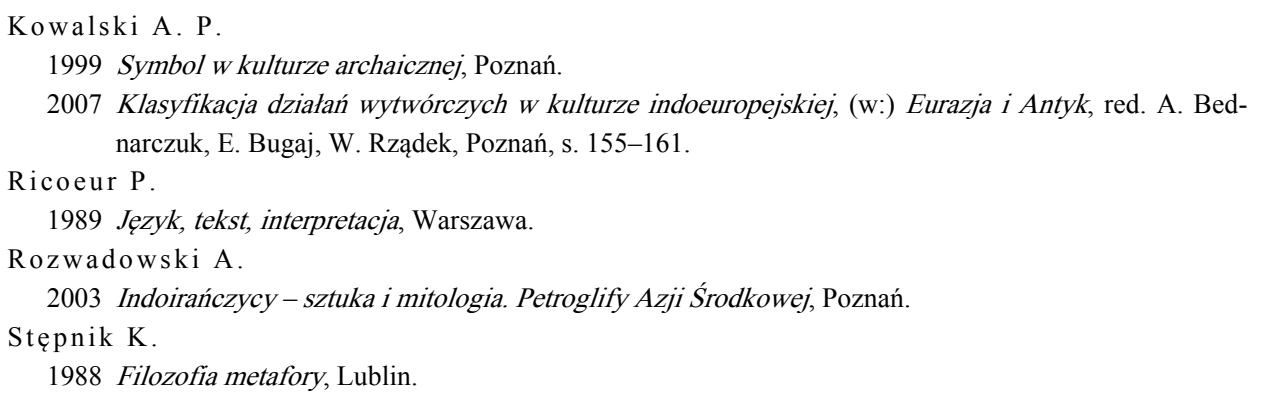

Sum mary

The study „Images from the Past: Hermeneutics of rock art” by Andrzej Rozwadowski presents the state-of-the-art of rock art studies. This innovative approach is embedded in existing theoretical impediments of these studies and refers to the newest methodological concepts of contemporary archaeology. The book refers in many instances to previous work by Rozwadowski - „Indo-Iranians - the art and mythology. The petroglyphs from Central Asia”. The author is critical of a heuristic potential of the so-called ethnographic analogies, however, he does not unquestionably reject a possibility of using them in rock art interpretation. He stresses a need of making adequate methodological assumptions, in particular referring to contextualization. It is understood as a point of departure in re-reading the rock art. Another significant element of his research proposal is use of metaphor facilitating different interpretations. This position is in accord with the author's understanding of semantic dynamism of rock art.

The study by Rozwadowski is a valuable book touching upon the relatively unknown theme in Polish archaeology. Thanks to accessible language and wide references to philosophy, linguistics, anthropology, botany and other sciences, this book proved to be successful in grasping a complexity of the problem.

\section{Karolina Harat}

Instytut Prahistorii, Uniwersytet im. Adama Mickiewicza ul. Św. Marcin 78, 61-809 Poznań, Poland 